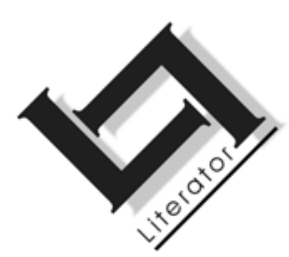

\title{
Zenobia's story: how a victim of abuse uses isiXhosa to account for her actions
}

\author{
M. Dlali \& S. Mokapela \\ Department of African Languages \\ University of Stellenbosch \\ STELLENBOSCH \\ E-mail:mdl@sun.ac.za \\ smokapela@parliament.gov.za
}

\begin{abstract}
Zenobia's story: how a victim of abuse uses isiXhosa to account for her actions

This article explores the theoretical work in articulating the motivations and conditions for account-giving in isiXhosa in relation to image restoration. The account-making process, according to Warren (1989), is like a life in motion in which individual characters are portrayed as moving through their experiences, dealing with some conflict or problem in their lives and at the same time searching for a solution. The narrator discovers at the age of twelve that the person she is referring to as her mother is not her real mother and that her real mother died while giving birth to her. The situation at home deteriorates after the death of her father. Her desperation is further fuelled when her stepmother marries a taxi-driver who sexually abuses her. The narrator then resorts to alcohol and drug abuse to cope with her growing sense of not belonging. The opportunity for changing her life and opening up endless avenues for progress and advancement comes when the narrator passes matric and, through her father's will, pursues her studies at a tertiary institution. She graduates as a top student and now practices as a medical doctor. This quest to understand the major stresses in each individual's mind is at the core of this article.
\end{abstract}




\section{Opsomming}

\section{Zenobia se storie: hoe 'n mishandelde slagoffer isiXhosa gebruik om haar verhaal te vertel}

Hierdie artikel ondersoek die teoretiese standpunte oor die motivering en omstandighede van selfvertellings in 'n isiXhosaverhaal van selfherstel. Volgens Warren (1989) is hierdie vertelproses soos 'n lewe in beweging waarbinne individuele karakters geskets word asof hulle deur verskillende ervarings beweeg en met sommige van die konflikte of probleme in hulle lewens handel en terselfdertyd 'n oplossing soek. Die verteller ontdek op twaalfjarige ouderdom dat die persoon wat sy as haar ma ken, nie haar regte ma is nie en dat haar regte ma gesterf het by haar geboorte. Die situasie by die huis gaan agteruit nadat haar pa sterf. Haar toestand versleg verder toe haar stiefma met 'n taxibestuurder trou wat haar seksueel misbruik. Die verteller neem gevolglik haar toevlug tot alkohol- en dwelmmisbruik om haar groeiende gevoel van nie-behoort te hanteer. Sy kry kans om haar lewe te verander en nuwe moontlikhede vir vooruitgang en verbetering te ontdek as sy matriek slaag en deur haar pa se boedel haar studie aan 'n tersiêre instelling kan voortsit. Sy gradueer as 'n uitstaande student en praktiseer as mediese dokter. Die soeke na begrip vir die spanning in elke individu se gedagtes vorm die kern van hierdie artikel.

\section{Introduction}

The importance of stories in our lives and the extent to which they serve as vehicles for rendering ourselves intelligible can never be underestimated. To say that we use stories to make ourselves comprehensible does not go far enough. Not only do we tell our lives as stories, there is also a significant sense in which our relationships with each other are lived out in a narrative. For White and Epston (1990:13) "persons give meaning to their lives and relationships by storying their experience". The ideal life, as proposed by Nehemas (1985), is one that corresponds to the ideal story, each act is coherently related to all others with nothing to spare. More cogently, Hardy (1968:5) has written that "we dream in narrative, daydream in narrative, remember, anticipate, hope, despair, believe, doubt, plan, revise, criticize, construct, gossip, learn, hate and love by narrative". Elaborating on this view, Maclntrye (1984) proposes that enacted narratives form the basis of moral character.

Narrative accounts are embedded within social action. They render events socially visible and typically establish expectations for future 
events. Because the events of daily life are, according to Gergen (1994), immersed in narrative, they become laden with storied sense: they acquire the reality of "a beginning", "a low point", "a climax", "an ending", and so on. People live out the event in this way, and along with others, they also index them in this way.

In this article we shall explore the nature of stories, both as they are told and as they are lived in social life. We shall begin with an examination of a story form, or, more formally, the structure of narrative accounts. We shall then consider the manner in which narratives of the self are constructed within social life and the uses to which they are put. As our account unfolds, it will become increasingly clear that narratives of the self are not fundamentally possessions of the individual but possessions of relationships products of social interchange. The account to be analysed for this article is a true life story that has been obtained by means of audiovisual material. All the examples that are quoted in the analysis refer to the account which is written in the appendix.

\section{Theoretical assumptions}

Gergen (1994) considers self-narratives as forms of social accounting or public discourse. In this sense, narratives are conversational resources; constructions open to continuous alteration as interaction progresses. Persons in this case do not consult an internal script, cognitive structure, or apperceptive mass for information or guidance; they do not interpret or "read the world" through narrative lenses, they do not anchor their own lives. Rather, the self-narrative is a linguistic implement embedded within conventional sequences of action. As linguistic devices, narratives may be used to indicate future actions, but they are not themselves the cause or determinant basis for such actions. In this sense, self-narratives function much like oral histories or morality tales within a society. They are, as proposed by Gergen (1994), cultural resources that serve such social purposes as self-identification, self-justification, self-criticism, and social solidification.

Scholars concerned with narratives are sharply divided on the issue of truth value: many hold that narratives have the potential to bear truth, while others argue that narratives do not reflect but construct reality. The former view sees narrative as fact-driven, while the latter generally holds narrative to be fact-organising or even fact-producing. Most historians, biographers, and empiricists understandably emphasise the truth-bearing possibilities of narrative. Because this assumption grants to cognition of an adaptive function, many cog- 
nitive theorists also plump for narrative verisimilitude. It is largely because of existing narrative forms that telling the truth is an intelligible act.

The importance of the intelligibility of accounts is established with reference to Schank and Abelson (1977) who contend that people construct accounts based on their knowledge, structure and approach, causal reasoning and text comprehension. Thus, for an account to be honored, it has to be goal-oriented and coherent. In this article, the social-interactive aspects of account-giving are investigated and it is discovered that severe reproach forms involving personality attacks and derogatory aspects, elicit defensive reactions that result in negative interpersonal and emotional consequences.

\subsection{The structure of narrative accounts}

From the constructionist standpoint, the properties of well formed narratives are culturally and historically situated (Gergen, 1994). They are byproducts of people's attempts to relate through discourse, in much the same way that styles of painting serves as a means of mutual coordination within communities of artists or specific tactics and countertactics become fashionable within various sports. To understand how narratives must be structured within the culture is to press against the edges of an envelope - to discover the limits to identifying oneself as a human agent in good standing; it is also to determine what forms must be maintained in order to acquire credibility as a teller of truth. The structure of proper storytelling precedes the events about which truth is told; to go beyond the conventions is to engage in an idiot's tale. Thus, rather than being driven by facts, truth telling is largely governed by a forestructure of narrative conventions.

There have been many attempts to identify the characteristics of a well-formed narrative. They have occurred within the domains of literary theory (Frye, 1957; Scholes \& Kellogg, 1966; Martin, 1987), semiotics, (Propp, 1968; Rimmon-Kenan, 1983), historiography (Mink, 1969, Gallie, 1964), and certain sectors of social science (Labov, 1982; Sutton-Smith, 1979; Mandler, 1984). Our attempt draws on these various analyses. Theorists frequently make claims for a foundational or fundamental set of rules or characteristics of the wellformed narrative. This analysis, however, sees narrative constructions as historically and culturally contingent. 
Narrative accounts, based on McIntyre (1984) form the basis of moral and social events and as such, stories have two elements through which they are explored. They are explored firstly in the way they are told and secondly, in the way they are lived in social context. These stories follow a historically or culturally based format, and to this effect Gergen (1994) suggested narrative criteria that constitute a historically contingent form. Narrative forms are linguistic tools that have important social functions to satisfactorily fulfil such as stability narrative, progressive narrative and regressive narrative. According to Gergen (1994), self-narratives are social processes in which individuals are realised on account of the personal perspective or experience, and as such, their emotions are viewed as constitutive features of relationship. The self narrative used and analysed in this article portrays the contemporary or segments of a well-formed narrative.

\section{- $\quad$ Theme, goal}

The theme of this narrative is child abuse and its consequences. The narrative illustrates this theme by showing how a young girl, Zenobia, has been systematically abused by her stepmother and later also by her stepfather. The narrative shows the consequences of this abuse on the girl: drug abuse and promiscuity. At the end, she realised that she should accept her problem and seek help.

\section{- Selection of events in a narrative}

Events in a narrative have a distinctive structure. Such a structure is formed through the linking of separate events into a series of events. These smaller series of events are linked together into a narrative cycle.

\subsection{Series of events}

The narrative on child abuse has been divided into a number of smaller series of events. The events in the life of the narrator have been selected with the theme in mind. Only those events have been included which have relevance to the theme of the narrative, i.e. abuse of children and its consequences.

The introduction to the narrative links up with the end of the narrative. The narrator introduces herself as an alcoholic but at the same time she is trying to solve this problem because she has accepted that she has a problem. 


\subsubsection{First series of events: childhood of narrator}

The first series of events consist of three separate events: adoration of father, father's death, and the period after her father's death.

\section{- Adoration of father}

The narrator has feelings of unworthiness because of being hated by her mother. At the same time she is adored by her father who is only at home during weekends. With her father present, even her mother treats her well. This treatment leaves the narrator confused.

Ekukhuleni kwam, ndingumntwana bendizungezwa ziimvakalelo zokuba ngumntu ongenaxabiso, ongelolutho nokungasazi esona sizathu senza ukuba umama wam angandithandi kangaka. Ndandihlala ke ngoko ndinolangazelelo lokufika kukaLwesihlanu, mini leyo utata wayedla ngokufika ngayo esuka emsebenzini njengoko wayexelenga kude nekhaya. Ndandifumana impatho efanayo naleyo yenkosazana xa ekhona utata kwaye ke le mpatho ndandiye ndiyifumane nalapho kumama into ke leyo ayayindikhwanqisa maxa wambi.

As a child, I have been haunted by the feelings of unworthiness and not knowing why my mother hated me. I used to look forward to Fridays when my father comes home from work as he was working away from home. When he was around, I always got the princess kind of treatment even from my cruel mother.

The above event is the narrator's memory of her childhood life.

\section{- Father's death}

The narrator's father becomes ill and was hospitalised. This brings on feelings of loneliness in the narrator. After her father passes away, she gets no comfort or sympathy. She also discovers that her real mother passed away at her birth. The one she thought of as her mother is in reality her stepmother.

Oku kuqhubekile de ndaba neminyaka elishumi elinesibini apho izinto ziqale ukuba maxongo nangakumbi, utata egulela oogqirha nezicaka esibhedlele. Ndandingasenaye ngoku umntu ondibiza nkosazana ukanti nalowo undiqinisekisa ngekamva eliqaqambileyo, indim othe ngcu phaya phezu kwento zonke zelizwe ngokubanzi. Uye wasweleka utata emva kweenyanga ezintathu egula. Akuzange kubekho nomntu ondithuthuzelayo novelana nam, kwakungathi andibonakali ndifana nje nomoya. Kungalo eli lixa ke apho ndafumanisa ukuba kanti lo mntu ndimbiza ngokuba ngumama akanguye, oyena mama wam wasweleka efumana mna lo. Nangona zazibuhlungu ezi ndaba 
zazisichaza isizathu esenza ukuba umama andicaphukele kangaka.

This continued until I was twelve years old when things started to get worse, with my father being critically ill and confined in hospital. No one was calling me Princess anymore or assuring me of a brighter future with me on top of the world. Three months later my father passed away. No one sympathised with me; it was as if I did not exist and that was the time I learnt or discovered that my real mother died while giving birth to me, and that this one is my stepmother. Somehow, that explained the reason why she hated me so much.

This event is the central part of the narrative. The death of the narrator's father is not the only issue in this case, but there is also the discovery that the narrator's mother passed away when the she was born. The latter information is useful in that it made it easier for the narrator to understand why her mother was so malicious to her.

\section{- The period after her father's death}

Life at home deteriorates. The narrator had no relatives to turn to. Her feelings of loneliness deepen. She blames herself for her mother's death. Her stepmother regards her as a burden and would like to be rid of her. Because of this, the narrator begins to see herself as a burden.

Imeko yasekhaya yaya isiba mbi nangakumbi kwabe kungekho nto ndandinokuyenza ngayo nanjengoko kwakungekho bani endandinokubalekela kuye. Ndandingazi zizalwane zimbi ngaphandle komama lo endihlala naye, ndingenazo nezo nkcukacha ngomama wam owandizalayo, into endandiyazi ngaye kukuba wasweleka ezala mna lo. Nokuba ndandinokuzincama ndimbuze umama lo kwakungekho ncedo ndandinokulufumana kuba naye wayedla ngokushwabula maxa wambi ngelithi ukuba ebebazi "abantu bakulonyoko" wam ebenokwahlukana nolu xanduva lundim njengokuphanyaza kweliso.

The situation at home got worse day in and day out and there was nothing I could do about it, as I had no one to turn to or run to. I didn't know any other family (extended) members or relatives for that matter and I had no information about my real mother's family or background, all I knew was that she died giving birth to me. I really blamed myself for that and I don't know why. I could not ask my mother as she used to mention that if she knew my real mother's family, she would get rid of this burden (that is me) at the blink of an eye. 
It is obvious in the above event that now that the narrator's pillar and beacon of love and hope is gone, the mother would be even more malicious towards her. Neglecting the girl is not unusual or unexpected, but marrying someone who would molest and rape the child without her noticing is extreme, even in this community. To hide away and drown the pains and sorrows, the narrator starts drinking and using drugs with the assistance of her stepfather.

\subsubsection{Second series of events: remarriage of stepmother}

The second series consists of two events: the marriage and the abuse.

\section{- $\quad$ The marriage}

The narrator's stepmother marries a taxi-driver. At that time the narrator is fifteen years old. Zenobia and the new husband do not like each other.

Emva nje kweminyaka emibini utata eswelekile umama uye watshata nomnye umntu ongunoteksi, besele ndineminyaka ephantse yaba lishumi elinesihlanu ngoko. Le ndoda iye yazokuhlala nathi apha emzini katata. Ndandingamthandi lo mntu naye ndimazi ukuba akandithandi kwaye sobabini singakwazi ukuzifihla iimvakalelo zenzondo omnye komnye.

She got married to a taxi-driver eighteen months after my father's death, and by that time I was almost fifteen years old. This man moved with us in my father's house and I did not like him as much as he did not like me. We could not hide our hatred towards one another.

\section{- Abuse}

The stepmother and her new husband are heavy drinkers. The narrator is repeatedly raped by her new stepfather. He threatens to kill her if she reports the abuse. She does not report it. She also starts her abuse of alcohol and drugs and at sixteen years she is also a heavy drinker.

Bobabini babengala aphume izandla amanxila kunge bayaphikisana. Wayesithi ke xa ayotyiweyo okanye ethe nantya kukunxila umama lo, achwechwe umshologu omdala ukuza egumbini lam afike andidlwengule andithembise ngokundibulala ukuba ndikhe ndayithetha le nto kuye nabani na. Ngeso sizathu ke ndayitshixela kum ngaphakathi le mbandezelo, ndanyamezela ukuba sisigculelo seso sibhovu-bhovu sesidlwengu. Ndithe ndisiba neminyaka elishumi elinesithandathu ndabe 
ndisiya ngamandla ebhotileni yeenyembezi zikaVitoliya kwaye lo tata engonqeni ukundithengela utywala de wandifaka nakulo mkhuba wecuba labathwa.

They were both heavy drinkers and when my mother passed out, her husband would sneak into my room, fondle with me and then rape me. He promised to kill me if I told or even hint about this to anyone. That was true and as a result I kept my mouth shut while he continued to entertain himself with my body. By the time I was sixteen, I was a heavy drinker already and this man used to buy me booze and started me on marijuana.

\subsubsection{Third series of events: narrator's education}

\section{- $\quad$ Studies}

The narrator passes matric at nineteen and she goes to university to study medicine. Her late father has made provision for her studies in his will. She continues abusing herself but she finishes her studies with distinction. She never returns home and when she finishes her degree, her stepmother and stepfather do not attend her graduation.

Ndiliphumelele ibanga leshumi xa ndineminyaka engama-19 ndaze ndaya e-Unitra (IDyunivesithi yaseTranskei) ndiyokwenza izifundo zobugqirha (MB.Ch.B.). Le yinto endandisoloko ndiyifuna kwathi kanti notata unduluke ewenzile amalungiselelo okuba ndiphumeze amaphupha am ngokwezicwangciso ezisegqwetheni lakhe. Nangona ndiphumile kula nkxwaleko yekhaya, andikwazanga kuyeka ukusela, ukutshaya umya ukanti nokulala nayo nayiphi na indoda ethe yafuna ukulala nam kwaye ndandingaboni nto isisikhwasilima kulo nto. Ukanti bekusithi nokuba ayiphindanga ize kundibona indoda leyo ndingaboni nto igwenxa nephosakeleyo kulo nto kuba ukusetyenziswa ngokwesini ibiyinto ebufana nesithethe kum.

Ndiqhube kakuhle kakhulu nezifundo zam, ndiphumelela emagqabini, ukanti ke andizange ndiphinde ndiluthi cakatha olwam ekhaya oko ndahamba ngala mhla ndandisiya eUnitra. Imini eyona yakha yamyoli ebomini bam yimini esasithweswa ngayo izidanga apho ndathi ndafumana esona sipho, imoto esuka kutata ithengwe ligqwetha lakhe ngokomyolelo wakhe. Ndonwaba ngolona hlobo. Umama lo kunye nezuma lomyeni wakhe, zange babonakale nangetshengele.

I passed my matric at the age of nineteen and went to Unitra (the University of Transkei) to do my MB.Ch.B., because that's what l've always wanted to do and my father had made pro- 
visions for that through his lawyer. Even there, I never stopped drinking and sleeping around with men was not such a big deal, and I was not bothered if a man never made a follow-up on me. Being used as a sex object by men especially those closest to me and drinking it off was a norm to me.

I progressed well with my studies and I never set my foot back to my so-called home since the day I left for University. On my graduation day, I received a car as a present from my late father arranged by his lawyer per his bequest or will. My socalled mother and her husband didn't make any appearance and I am sure they were drunk as usual.

\section{- After graduation}

The narrator now practices as a doctor but she kept on abusing herself with alcohol and drugs. She feels degraded because of the loss of her dignity and youth through cruelty. As a teenager she had already become promiscuous and addicted to alcohol and drugs. As an adult, she is still dealing with the aftermath of this.

Andizange ndiyeke ukuyotywa nangona besendingugqirha nje, akukho nto ndiyifunayo ndingakwazi kuyifumana kungekho nandawo ndingakwazi kufikelela kuyo nendifunayo ukufika kuyo. Kodwa konke oko akunakulinganiswa nesidima sam kunye nobutsha bam obohluthwa kum ngenkohlakalo. Abantu abaninzi basabona laa Zenobia waseMakerere. Ndithi ke basabona laa Zenobia unesimilo esithe saa. Akukho nanye kwiitshomi zam ezingabafana endingazange ndilale nayo kuba ndandingafuni ukulahlekwa bubuhlobo nazo, kwaye ndandiyazi leyo nto yokunikezela ngomzimba wam iyeyona ndlela abanokundamkela ngayo.

I continued hitting the bottle. Yes, I am the doctor now and I can afford anything I want, but all that is not worth my dignity and my youth which I lost through cruelty. I know that most people when looking at me still see that Zenobia from Makerere. I slept with almost all my male friends, because that was the only way I knew of making people love and accept me.

\subsubsection{Fourth series of events: rehabilitation}

The narrator attends AA meetings for her alcoholism. She used to blame her stepmother and stepfather for her problems but she now accepts that ultimately she is the only one who can change her life.

Njengoko besenditshilo, impilo nobomi bam abundonwabisi kwaye ndiyazi ukuba akakho omnye umntu onokuzisa utshint- 
sho ebomini bam ngaphandle kwam. Ndizimisele ekuguquleni impilo yam ibe yencomekayo, yiyo loo nto ndithathe isigqibo sokuba ndihambe ezi ntlanganiso zakwa AA. Lide ixesha ndikhombe umnwe obek'ityala kumama lo wam kunye nomyeni wakhe, nangona ndingetsho nje ukuba bamsulwa kuba ke eneneni abasokuze babe msulwa, kodwa ndiyayazi into yokuba umntu onokwenza ubomi bam bube bobo bungumzekelo kwabanye ndim kuphela.

I am not happy with the way things are and I know that no one else but me could change that or put an end to it. This is basically the reason why I am attending the AA meetings. I have been blaming my stepmother and her husband for the way things turned out with me, and to a certain extent they both are accountable, but it is only me who can put an end to it all.

In this rehabilitation phase, the narrator decides to shape-up her life by addressing her alcohol addiction. She has also come to realise the fact that there is no one who can bring positive change to her life but herself, and as such she seems ready and eager to take the first step towards that change.

\subsection{The three phases in the narrative}

According to Brink (1987), events in a narrative do not appear as separate pieces of information, but they have a tendency to follow a certain sequence which is arranged into episodes. This helps to develop the story in a meaningful narrative text. This organisation is most important in the arrangement of events in any narrative text. Brink also maintains that every story is divided into three phases: the beginning, the middle and the end. In modern terminology these three phases are called virtuality, actualisation and conclusion. Virtuality is the presentation of circumstances that will make it possible for a change to take place. Actualisation is the fulfillment of the event. In the conclusion we find the result of the fulfillment.

\section{- Beginning}

The set of circumstances which leads to a change in the narrator are the following: the cruelty of her stepmother, the death of her father and the abuse by her stepfather.

\section{- $\quad$ Middle}

The change in the narrator is clear through her promiscuity and selfabuse through alcohol and drugs. 


\section{- End}

The result of this process of self-abuse is the ultimate realisation that she should take charge of her own life and seek help.

\subsection{Ordering of events}

\section{- Linear sequence}

The events in this narrative are ordered in a linear sequence:

- We first meet the narrator as a child with a cruel stepmother and a loving father.

- Then her father dies when she was twelve years old.

- After that her stepmother remarries when the narrator is fifteen years old and this marriage results in her being abused.

- She passes matric and goes to university to study medicine.

- She finishes her medical degree and begins practicing as a doctor.

- She then goes for rehabilitation.

\section{- Duration}

The duration of this narrative extends from the childhood of the narrator up until she is 34 years old.

\section{- Stability of identity}

The narrator does not seem to have a coherent identity. It seems as if she has a dual personality: on the one hand she is quite timid and easily influenced, but on the other hand she is strong and obtains success.

Her timid qualities can be seen in the following events:

- She is unworthy: "umntu ongenaxabiso".

- She in unloved and hated: “... umama wam angandithandi kangaka ..., ... umama lo andicaphukele kangaka, ... naye ndimazi ukuba akandithandi".

- She is lonely: “... ndandingasenaye umntu ..., ... akuzange kubekho mntu undithuthuzelayo ..., kwakungekho bani endandinokubalekela kuye". 
- She feels herself a burden: “... nolu xanduva lundim”.

- She is weak: “... ndayitshixela kum le mbandezelo, ... andizange ndiyeke ukuyotywa, ... into yokunikezela ngomzimba wam, ... oko ndandikuxolele ..."

Her strong qualities can be seen in the following circumstances:

- She is determined and resolute: she passed matric and her studies at the university with distinction; she practices as a doctor.

- She persevered: “... akakho omnye umntu onokuzisa utshintsho ebomini bam". (... There is no other person who can bring change in my life.)

\section{- Causal linkages}

The events in a narrative are causally linked and they do show a relationship between cause and effect. In the beginning, the narrator mentions that she learns at her father's funeral that the mother she was staying with was not her real mother, and that explains the reason why she was hated by this woman. Secondly, the narrator is sexually abused by her stepmother's husband. As a result she resorts to alcohol and drugs to escape from her predicament. At the university, the narrator sleeps around with her male friends and allows herself to be financially abused by her female friends because all she wants is for them to accept her in their circles. Lastly, she decides to attend the AA meetings because she has come to realise that the only one who can bring positive change in her life is herself.

\section{- The narrative form}

This story has a regressive narrative. At first the narrator is haunted by the feelings of unworthiness and not knowing why her mother hates her so much. Whilst trying to find out why her mother hates her, she loses her father, the only positive thing in her life that brings joy and hope for better things to come. She learns that her mother is actually her stepmother and she is never able to trace her real mother's family. From there, her stepmother marries a paedophile that not only used the young girl as a sex object, but he introduces her to drugs and alcohol. She continues with this newly found norm of sleeping around with any man and using alcohol and drugs, but she is never happy with that or herself. She is now a doctor with all the comfort the world has to offer, but still not happy or at peace with herself. 
This narrative is also a progressive narrative because the narrator does change eventually, when she decided to take the blame for her situation on herself. She then begins attending AA meetings for her alcoholism.

\section{Self-narrative}

\subsection{Social accounting}

The social purpose that this narrative fulfils is that of self-justification in that the narrator continues to mention her upbringing and her stepmother as the sole perpetrators. In a way, not having motherly love, protection and guidance are the reason for her addiction and promiscuity.

Another social purpose that this narrative is fulfilling is that of selfcriticism because somehow the narrator does take full responsibility of her sleeping around with men and using drugs especially during her tertiary education and after she graduates as a doctor. By admitting responsibility, she is not condoning what her stepmother and her husband did to her, but she is acknowledging the fact that she is the only one who can positively turn her sordid life around.

\subsection{Narrative is true.}

This narrative is accepted as true in most South African communities in that it is a well known fact that stepmothers are very malicious especially towards their stepchildren. Cases of incest are apparent in our societies particularly in the 21 century, and children subjected to that are most likely to turn out as drunkards, drug abusers and/or prostitutes. Most of them become what is known as "oo-bergie" because they are mostly subjected to this abuse at a very tender age. Most people are going to relate to this narrative particularly the survivors of child abuse and molestation.

This narrative may help most households and people in the same situation as Zenobia to realise that if you put your mind into it, you might see a light at the end of the tunnel.

\section{Practices of self-narration: process}

\section{- Relationship among life experience}

The narrator at first depicts her life as unstable and gradually in a steep decline. From the beginning of the narrative she experiences life as not worth living because of the attitude of her stepmother 
towards her. Later on, this decline is emphasised through the abuse of her stepfather and her own self-abuse through alcohol, drugs and promiscuity. But, although she depicts her life as a slow decline in self-abuse, her narrative clearly shows signs of a positive narrative with which she is able to gradually improve herself and to find a new purpose. This is evident because of two issues in her narrative: firstly, she is able to progress rapidly and with distinction in her studies, eventually qualifying as a doctor, and secondly, she takes hold of her life by accepting her alcoholism.

\section{- Micro narrative}

This is a micro narrative in that the events of the narrator's personal life occur over a short period of time, from when she is a young child until she is almost 34 years old. This narrative only explores one central issue in her life and does not depict all her experiences.

\section{- $\quad$ Pragmatics of self-narrative}

This narrative is basically a regressive narrative as indicated above. The issue to be considered here is the social value of such a regressive narrative. The narrative solicits sympathy because it is a tale of woe: the systematic abuse of a young girl. Thus, the narrative solicits pity and concern because of this abuse. But at the same time, the narrative is seen as a challenge to seek improvement and is therefore also progressive. The narrator made specific efforts to turn back from her tragedy: she performs well at school and attends AA meetings. Thus, this regressive narrative "serves as an important means for motivating people toward achieving positive ends" (Gergen, 1994:207).

\section{Interknitting of identities}

\section{- Moral evaluation}

There are two issues which have to be considered with regard to moral evaluation of the narrative. Firstly, the community clearly sees the result of the abuse: alcoholism, drug abuse and promiscuity. No community will condone such behavior and thus the narrative will be seen in a negative light and the narrator as a typically corrupt person with no morals. The outward signs of this corrupt life seem to be clear. Secondly, the narrative seems to be contradictory to the telling. While the narrator depicts herself as a morally corrupt person, she is at the same time taking deliberate steps to advance herself as is evident in her academic achievements. In this way, the community may be divided in their evaluation: on the one hand, a clear negative 
evaluation of moral decline, but on the other hand, signs of improvement in her life which will give rise to a positive evaluation.

\section{- Interminable negotiation}

There is clear ambiguity in this narrative as shown in the above paragraph. It is problematic to see whether there is narrative validity within the community where she grew up. The narrator does not sustain one specific identity in this narrative. Her actions do not measure up to expectations. There is a basic contradiction in this narrative: one expects a totally degraded abused character because of her negative actions of self-abuse, but at the same time she progresses in life. Thus, she does not maintain one identity.

\section{- Reciprocal identities}

The actions of the stepmother and stepfather contribute vitally to the events in the narrative. The narrator lays the blame for her immoral conduct squarely on the shoulders of these two characters: the stepmother because of her cruelty and the stepfather because of his abuse. Thus, she is able to justify her actions because of these two people.

\section{- Emotions}

The narrator experiences a variety of emotions. Firstly, she shows clear signs of sadness because of the neglect by her stepmother and the death of her father. But at the same time, she has a positive emotion of love towards her father. Then she has an emotion of anger because of being abused by her stepfather. Lastly, she shows an emotion of acceptance of her ill-treatment because she deliberately starts with self-abuse of alcohol and drugs.

Such emotions as sadness and anger are accepted within isiXhosa culture because they are usually the result of neglect, death and abuse. However, acceptance is not generally approved of because it leads to self-abuse as in the case of this narrative. Acceptance in the positive sense of this emotion may also be frowned upon as it leads to negative actions such as treating oneself as unworthy.

The emotional expressions of sadness, anger and acceptance in this narrative are meaningful because they are expected by the community after the negative treatment of the narrator at the hands of her step-parents.

The hostility in this narrative is only directed at the narrator herself as is evident from her self-abuse. Such hostility is viewed very nega- 
tively because there are various other ways towards which one may direct such hostility.

\section{Conclusion}

In the light of the above discussion, the narrator has shown that she is committed to restore her image despite her upbringing or the problems she encountered as a child. The first thing she does is to give an account of what happened to her as a child and why she is now talking about it. In this way, she has managed to take part of the problem off her shoulders and she also achieves a sense of relief from her shame. Although she is the victim of abuse, she is not prepared to let that ruin her life. That is why she is talking freely about how her life has been and the steps she has taken to rectify it. Of interest is the fact that although the narrator blames her stepparents for the ill-treatment she has endured, she is aware that only she can improve her condition in life. People who have experienced similar abuse or neglect often keep this a secret. Similarly, most people who are HIV positive do not disclose their status. Zenobia's story might show people that instead of shifting the blame to others for their failures or accusing other people, they should take part of the responsibility as well as the necessary steps to improve their lives.

It has been found in this article that when people are reproached for a social failure, they feel obliged to construct an account for the failure event, an account that will be honored by the reproachers. An account can also refer to the narratives or stories that we use to explain and make sense of a social interaction, and it can refer to the way in which people try to affect a repair of a social failure. The only way that an accounter can be able to address the most significant issues when accounting, is to consider the failure event for which he/she is reproached and come into terms with the issue that he/she has to account for.

\section{List of references}

BRINK, A.P. 1987. Vertelkunde. Pretoria: Academia.

FRYE, N. 1957. Anatomy of criticism. Princeton: Princeton University Press.

GALLIE, W.B. 1964. Philosophy and the historical understanding. London: Chatto \& Windus.

GERGEN, K.J. 1994. Realities and relationships: soundings in social construction. Cambridge: Harvard University Press.

HARDY, B. 1968. Towards a poetics of fiction: an approach through narrative. Novel, 2:5-14. 
LABOV, W. 1982. Speech actions and reactions in personal narrative. (In Tanner, D., ed. Analyzing discourse: text and talk. Washington: Georgetown University Press.

MACINTRYE, A. 1984. After virtue. 2nd ed. Notre Dame: University of Notre Dame Press.

MANDLER, J.M. 1984. Stories, scripts and scenes: aspects of schema theory. Hillsdale: Erlbaum.

MARTIN, E.M. 1987. The woman in the body: a cultural analysis of reproduction. Boston: Beacon.

MINK, L.A. 1969. History and fiction as modes of comprehension. New literary history, 1:556-569.

NEHEMAS, A. 1985. Nietzsche: life as literature. Cambridge: Harvard University Press.

PROPP, V. 1968. Morphology of the folktale. Austin: University of Texas Press.

RIMMON-KENAN, S. 1983. Narrative fiction: contemporary poetics. London: Methuen.

SCHANK, R.C. \& ABELSON, R.P. 1977. Scripts, plans, goals and understanding. Hillsdale: Erlbaum.

SCHOLES, R. \& KELLOGG, R. 1966. The nature of narrative. Oxford: Oxford University Press.

SUTTON-SMITH, B. 1979. Presentation and representation in fictional narrative. New directions for child development, 6:37-60.

WARREN, C. 1989. The art of translation: voices from the field. Boston: North Eastern University Press.

WHITE, M. \& EPSTON, D. 1990. Narrative means to therapeutic ends. New York: Norton.

Key concepts:

account-giving

identity

narrative account

self-narrative

Kernbegrippe:

identiteit

self narratiewe

storievertelling

verslagdoening 


\section{Appendix}

NdinguZenobia*, ndineminyaka engama-34 kwaye ndilinxila. Abantu bayakuthanda ke ukusoloko befing'iintshiya okanye beshwacel'amabunzi qho xa ndichaza ukuba ndilinxanwa. Asikuko ke nokuba ndiyazingca okanye ndiyakonwabela ukuba linxila, kuloko oku bekuyeyona ndlela ndiyaziyo yokuzifihla kwiinkxwaleko neenzima zeli hlabathi. Ngawo lo mzuzu ndiziva ndinochulumanco ukuvakalisa ukuba ekugqibeleni kukho into endiyenzayo ngako oko.

Ekukhuleni kwam, ndingumntwana, bendizungezwa ziimvakalelo zokuba ngumntu ongenaxabiso, ongelolutho nokusazi esona sizathu esenza ukuba umama wam angandithandi kangaka. Ndandihlala ke ngoko ndinolangazelelo lokufika kukaLwesihlanu, mini leyo utata wayedla ngokufika esuka emsebenzini nanjengoko wayexelenga kude nekhaya. Ndandifumana impatho efanayo naleyo yenkosazana xa ekhona utata kwaye ke le mpatho ndandiye ndiyifumane nalapho kumama into ke leyo eyayindikhwankqisa maxa wambi.

Oku kuqhubekile de ndaba neminyaka elishumi elinesibini apho izinto ziqale ukuba maxongo nangakumbi, utata egulela oogqirha nezicaka esibhedlele. Ndandingasenaye ke ngoku umntu ondibiza nkosazana ukanti nalowo undiqinisekisa ngekamva eliqaqambileyo, indim othe ngcu phaya phezu kwento zonke nelizwe ngokubanzi. Uye wasweleka utata emva kweenyanga ezintathu egula. Akuzange kubekho mntu undithuthuzelayo novelana nam, kwakungathi andibonakali ndifana nje nomoya. Kungalo eli lixa apho ndafumanisa ukuba kanti lo mntu ndimbiza ngokuba ngumama wam akanguye, oyena mama wam wasweleka efumana mna lo. Nangona zazibuhlungu ezi ndaba kodwa zazisichaza isizathu esenza ukuba umama lo andicaphukele kangaka.

Imeko yasekhaya yaya isiba mbi nangakumbi kwabe kungekho nto ndandinokuyenza ngayo nanjengoko kwakungekho bani endandinokubalekela kuye. Ndandingazi zizalwane zimbi ngaphandle komama lo endihlala naye, ndingenazo nezo nkcukacha ngomama wam ondizalayo, into endandiyazi ngaye kukuba wasweleka ezala mna lo. Nokuba ndandinokuzincama ndimbuze umama lo kwakungekho ncedo ndandinokulufumana kuba naye wayedla ngokushwabula maxa wambi ngelithi ukuba ebebazi "abantu bakulonyoko" wam ebenokwahlukana nolu xanduva lundim njengephanyazo Iweliso.

Emva nje kweminyaka emibini utata eswelekile umama lo uye watshata nomnye umntu ongunoteksi, besele ndineminyaka ephantse yaba lishumi elinesihlanu ngoko. Le ndoda iye yazokuhlala 
nathi apha emzini katata. Ndandingamthandi tu lo mntu naye ndimazi ukuba akandithandi kwaye sobabini singakwazi ukuzifihla iimvakalelo zenzondo omnye komnye. Ngeenyanga nje ezintathu lo mntu elapha, zaqala ukwenzeka izinto ezona zakha zaba mbi.

Bobabini babengala aphume izandla amanxila kunga bayakhuphisana. Wayesithi ke xa ayotyiweyo okanye ethe natya kukunxila umama lo, achwechwe umshologu omdala ukuza egumbini lam afike andidlwengule andithembise ngokundibulala ukuba nje ndikhe ndayithetha le nto kuye nabani na. Wayede athi nokuba ndingayithetha, umama lo akasokuze andikholelwe kuloko uya kusuke amncedise ekundibulaleni. Ndandikukholelwa oku kuba naye umama wayengandifuni nyhani, wayehleli nje nam kuba engenacebo limbi. Ngeso sizathu ke ndayitshixela kum le mbandezelo, ndanyamezela ukuba sisigculelo seso sibhovu-bhovu sesidlwengu. Ndithe ndisiba neminyaka elishumi elinesithandathu ndabe ndisiya ngamandla ebhotileni yeenyembezi zikaVitoliya kwaye lo tata engonqeni ukundithengela utywala de wandifaka nakulo mkhuba wecuba labathwa.

Ndiliphumelele ibanga leshumi xa ndinemimyaka eli-19 ndaze ndaya edyunivesithi ndiyokwenza izifundo zobugqirha (MB, Ch.B). Le yinto endandisoloko ndiyifuna kwathi kanti notata unduluke ewenzile amalungiselelo okuba ndiphumeze amaphupha am ngokwezicwangciso ezisegqwetheni lakhe. Nangona ndiphumile kula nkxwaleko yasekhaya, andikwazanga kuyeka ukusela, ukuwutshaya umya ukanti nokulala nayiphi na indoda ethe yafuna ukulala nam kwaye ke ndandingaboni nto isisikhwasilima kuloo nto. Ukanti bekusithi nokuba ayiphindanga ize kundibona indoda leyo ndingaboni nto igwenxa nephosakeleyo kulo nto kuba ukusetyenziswa ngokwesini ibiyinto ebufana nesithethe kum.

Ndiqhube kakuhle kakhulu nezifundo zam, ndiphumelela emagqabini, ukanti ke andizange ndiphinde ndiluthi cakatha olwam ekhaya oko ndahamba ngala mhla ndisiya e-Unitra. Ngexesha leholide bendidla ngokuhamba ndiyohlala nabahlobo ndisebenzise imali ebendiyifumana inyanga nenyanga ngokwezicwangciso zikatata wam.

Imini yona eyakha yamyoli ebomini bam yimini esasithweswa ngayo izidanga apho ndathi ndafumana esona sipho, imoto esuka kutata ithengwe ligqwetha lakhe ngokomyolelo wakhe. Ndonwaba ngolona hlobo. Umama lo kunye nezuma lomyeni wakhe zange babonakale nangetshengele. 
Andizange ndiyeke ukuyotywa nangona besendingugqirha nje, akukho nto ndiyifunayo ndingakwazi kuyifumana kungekho nandawo ndingakwazi ukufikelela kuyo endifunayo ukufika kuyo. Kodwa konke oko akunakulinganiswa nesidima sam kunye nobutsha bam obohluthwa kum ngenkohlakalo. Abantu abaninzi xa bendijongile basabona laa Zenobia wasedyunivesithi eMakerere ukutsho oko kuba sasiyibiza ngolo hlobo. Ndithi ke basabona laa Zenobia unesimilo esithe saa. Akukho nanye kwiitshomi zam ezingabafana endingazange ndilale nayo kuba ndandingafuni ukulahlekelwa bubuhlobo nazo, kwaye ndandiyazi le nto yokunikezela ngomzima wam iyeyona ndlela abanokundamkela ngayo. Ngaxeshanye, abahlobo bam abangamantobazana babengamanxila nje afanayo nam, bekwatshaya nentsangu kwaye ke ukufumaneka kwezo zinto kwakuxhomekeke apha kum. Ndandiyazi mhlophe kunjalo nje ukuba ndandisengwa ndijongwa njengomthombo wemali, kodwa oko ndandikuxolele egameni nje lokuba kuthiwe ndinabantu abaya kuhlala besecaleni kwam.

Njengoko besenditshilo, impilo nobomi bam abundonwabisi kwaye ndiyazi ukuba akakho omnye umntu onokuzisa utshintsho ebomini bam ngaphandle kwam. Ndizimisele ekuguquleni impilo yam ibe yencomekayo, yiyo loo nto ndithathe isigqibo sokuba ndihambe ezi ntlanganiso zakwa AA (Alcoholics Anonymous). Lide ixesha ndikhombe umnwe obek'ityala kumama lo wam nomyeni wakhe, nangona ndingetsho nje ukuba bamsulwa kuba ke eneneni abasokuze babe msulwa, kodwa ndiyayazi into yokuba umntu onokwenza ubomi bam bube msulwa bube ngumzekelo kwabanye, ndim kuphela. Ukuba kwenzeka ntoni ukuze kube nje akusenantsingiselo kakhulu ngoku, okuthethekayo kukuba ndingumntu oyintoni nonaliphi na igalelo elizweni. Kungoko ke ndigqibe kwelokuba mandiguqule ubomi bam kuqala ukuze ndikwazi ukuzisa inguqu kubomi babanye.

My name is Zenobia*, I am 34 years old and I am an alcoholic. People always flinch or cringe whenever I say the last part of my introduction, that of being an alcoholic. It's not as if I am proud of or enjoy being an alcoholic, but it was the only thing I could use to hide or run away from my demons both from my childhood and my adult life. Today I am really glad and proud to announce that I am finally doing something about it.

As a child, I have been haunted by feelings of unworthiness and not knowing why my mother hated me. I used to look forward to Fridays when my father comes home from work as he was working away from home. When he was around I always got the princess kind of 
treatment even from my cruel mother. Her behavior used to confuse me a lot as young as I was.

This continued until I was twelve years old when things started to get worse, with my father being critically ill and confined in hospital. No one was calling me Princess anymore or assuring me of a brighter future with me on top of the world. Three months later my father passed away. No one comforted me or sympathised with me; it was as if I did not exist. That was the time I discovered that my real mother died when giving birth to me, and that this one was my stepmother. Although this news was very painful, it explained the reason why she hated me so much.

The situation at home got worse day in and day out and there was nothing I could do about it, as I had no one to turn to or run to. I didn't know any other family (extended) members or relatives for that matter and I had no information about my real mother's family or background, all I knew was that she died while giving birth to me. I really blamed myself for that and I don't know why. I could not ask my mother as she used to mention that if she knew my real mother's family, she would get rid of this burden (that is me) at the wink of an eye.

She got married two years after my father's death to a taxi-driver, and by that time I was almost fifteen years old. This man moved with us, in my father's house and I did not like him as much as he did not like me. We couldn't hide our hatred towards one another and within just three months, terrible things started happening. They were both heavy drinkers and when my stepmother had passed out, her husband would sneak into my room fondle with me and then rape me. He promised to kill me if I told or even hint about this to anyone, and even alleged that if I did mention it my stepmother would never believe me. Instead she would hate me even more and help him to kill me. That was true and as a result I kept my mouth shut while he continued entertaining himself with my body. By the time I was sixteen, I was a heavy drinker already and this man used to buy me booze and started me on marijuana.

I passed my matric at the age of nineteen and went to university to do my MB.Ch.B. because that is what I've always wanted to do and my father had made provision for that through his lawyer. Even there, I never stopped drinking and sleeping around with men was not such a big deal, and I was not bothered if a man never made a follow-up on me. Being used as a sex object by men especially those closest to me and drinking it off was a norm to me. 
I progressed well with my studies and I never set my foot back to my so-called home since the day I left for the university. During holidays I would go with friends and live on my allowance. On my graduation day, I received a car as a gift from my late father arranged or organised by his lawyer per his request or will. That was the happiest day of my life since my father's death, and I cried in a very long time wishing him to come back to me to celebrate this achievement with me. My so-called mother and her husband didn't make an appearance and I am sure they were drunk as usual.

I continued hitting the bottle. Yes, I am a doctor now and can afford anything I want, but all that is not worth my dignity and my youth which I lost through cruelty. I know that most people when looking at me still see that loose Zenobia from Makerere - as we used to call the University. I slept with almost all my male friends because that was the only way I knew of making people love and accept or rather stick with me. Almost all my female friends were heavy drinkers, smoking dagga and I used to buy those for them, by doing so they will stick with me all the time. I knew they were using me too, but that did not bother me that much so long as I have them by my side, for companionship.

I am not happy with the way things were or are with me or my life and I know that no one else but me could change that - put an end to it, sort of rewrite history. This is basically the reason why I am attending the AA meetings. I have been blaming my stepmother and her husband for the way things turned out with me, and to a certain extent they both are accountable, but it is only me who can put an end to it all. 
